DOI: https://doi.org/10.32839/2304-5809/2019-4-68-63

UDC 327.7:061.66

Proskurkina Iana

Taras Shevchenko National University of Kyiv

\title{
THE EXPERIENCE OF FOREIGN CULTURAL CENTERS FUNCTIONING
}

Summary. The article analyzes the practical experience of foreign cultural centers functioning on the example of their activity in Ukraine. It determines that foreign cultural centers are considered to be an important sector of the state policy thus such centers receive multi-faceted support from the state. It indicates that these organizations have different structure, as well as different model of budgeting, directions and forms of activities. The author focuses on the core activities of foreign cultural centers on the example of their Ukrainian branches work. Through the analysis of their activities, it can be shown that foreign cultural centers are a real tool for cultural and humanitarian state policy. To conclude, this paper will also consider actions that could be undertaken to improve the process of promoting Ukrainian national culture and language abroad.

Keywords: foreign cultural center, cultural representation, cultural cooperation, cultural project, external cultural and humanitarian policy.

Проскуркіна Я.I.

Київський національний університет імені Тараса Шевченка

\section{ДОСВІД ФУНКЦІОНУВАННЯ ЗАРУБІЖНИХ КУЛЬТУРНИХ ЦЕНТРІВ}

\begin{abstract}
Анотація. Інтенсифікація культурно-гуманітарного співробітництва України і необхідність позиціонувати себе на міжнародній арені сприяла появі культурного центру Український інститут, покликаного представляти українську культуру у світі. Розбудова такої інституції вимагає вивчення практичного досвіду діяльності подібних установ, які займаються розвитком міжкультурних зв'язків та реалізацією завдань зовнішньої культурної політики держави. На сьогодні вже багато країн світу створили такі організації. У статті аналізуеться практичний досвід роботи зарубіжних культурних центрів на прикладі їхньої діяльності в Україні. Для аналізу було обрано активні відомі міжнародні культурні інституції з найбільш розгорнутими представництвами зарубіжних культурних центрів, зокрема Великої Британії (Британська Рада), Франції (Французький інститут), Німеччини (інститут Гете) та інші, які є прикладом впровадження успішної політики культурної дипломатії і сприяють зміцненню міжнародних позицій країн, які вони представляють. Визначено, що зарубіжні культурні центри розглядаються як важливий сектор державної політики і отримують всебічну підтримку з боку держави. Було встановлено, що такі організації мають свої структурні особливості, а також свою модель фінансування, напрямки і форми діяльності. Особлива увага була приділена аналізу пріоритетних напрямків діяльності зарубіжних культурних центрів і фрорм роботи на прикладі роботи їніх українських філіалів. На підставі аналізу встановлено, що основними напрямками роботи діяльності таких центрів традиційно обираються культурний, освітній і науково-технічний напрямки, що обумовлено офіційними цілями роботи таких центрів, а саме пропагандою власної культури і формуванням позитивного іміджу країни. Зроблено висновок, що функціонування зарубіжних культурних центрів є важливим напрямком реалізації культурно-гуманітарної політики держав і визначено, які е можливості в плані практичного застосування перспективних набутків для більш ефрективної організації процесу просування української національної культури і мови за кордоном.
\end{abstract}

Ключові слова: зарубіжний культурний центр, культурне представництво, культурне співробітництво, культурний проект, зовнішня культурно-гуманітарна політика.

Tntroduction. The policy in the sphere of inter-

Inational cultural and humanitarian cooperation is an important part of Ukraine's foreign policy on the international arena. The complicated political situation makes important to develop cultural and humanitarian connections of Ukraine with other countries, and large-scale tasks in the sphere of international relations contribute to the intensification of cultural and humanitarian cooperation of Ukraine. Modern cultural and humanitarian cooperation is being implemented through various forms, in particular, the work of organizations representing the culture of a partner country abroad, the so-called foreign cultural centers, which activities include the implementation of various cultural projects. World practice shows that such institutions are important participants in the foreign cultural and humanitarian policy. The most active foreign cultural centers are ones of Great Britain, Germany, France. But today, many other countries, including Asian, such as China, Korea, are also making significant efforts to develop their foreign cultural centers. Such institutions are important participants in intergovernmental cooperation in the cultural and humanitarian segments.

At the same time, in Ukraine the idea of creating a cultural representation abroad appeared only in 2015: the Ministry of Culture developed a bill on the creation of the Ukrainian Institute (Taras Shevchenko Institute). As stated in the draft Statute of the Ukrainian Institute, the purpose of the Institute activities is to present Ukrainian contemporary culture and scientific innovations, to create the investment and touristic attractiveness of our country, to increase attractiveness of Ukraine abroad, and to integrate it into the world of artistic, scientific and educational space [1]. With the support of the Government, the Ukrainian Institute was created and started its functioning. The development of this institute has revealed a number of problems that arose due to lack of experience, inconsistency of actions of the state authorities involved in the creation of this institute.

That is why it is important to study the experience of foreign cultural centers of other countries. The study of the positive experience of the function- 
ing of such cultural institutions of other states may be useful in planning the further work of organizations promoting the culture of Ukraine abroad.

The aim of the study. In this paper, we aim to consider the experience of foreign cultural centers and explore the way how they function on the example of their Ukrainian branches.

The theoretical framework and research methods. Ukrainian scientists are actively exploring the issues of cultural and humanitarian cooperation, that are reflected in the works by V. Andrushchenko, O. Hrytsenko, I. Klyuchkovsky, V. Skuratovsky and others.

The experience of the activities of European foreign cultural institutions is considered in the analytical report by $\mathrm{O}$. Rozumnaya [2;3]. The author defines the necessary steps to promote the cultural presence of Ukraine abroad, especially in Europe.

In T. Grachevskaya's article the attention is paid to the analysis of priority activities undertaken by cultural information centers in the context of the implementation of cultural diplomacy of states, such as: providing information, coordination, educational services. The author emphasizes that cultural information centers are "important centers for providing the dissemination of information in the context of creating a positive image of states" [4].

The works by N. Bogolyubova and Yu. Nikolayeva deserve particular attention. In their works the authors explore the role of foreign cultural centers in the development of modern international diplomacy. An important part contribution of the authors is the implementing the definition "foreign cultural center" $[5 ; 6]$.

At the same time, researches on foreign cultural centers are still new and under development, which affects the work of the bodies involved in the setting up similar institution on the Ukrainian side. Therefore, it is reasonable to focus more on studying the experience of leading foreign cultural centers and their forms of activities. Such analysis will allow optimally to take into account the principles of organization, the experience of cultural centers functioning, to determine what are the opportunities in terms of practical application of promising achievements for a more effective promoting Ukrainian national culture and language abroad.

Research methods. Due to the nature of the study, to achieve the aim of this article we picked a qualitative research approach. We searched for the data via the official sites of the foreign cultural centers. We analyzed their documents, reports, the content of the programs etc. It made possible to evaluate their performance and global impact as well as and to define actions that could be undertaken to improve the process of promoting Ukrainian national culture and language abroad.

The results. A foreign cultural center is an organization that represents its country and its culture abroad, deals with the development of cultural ties, the formation of a positive image of the country abroad, realizes the political course of its country, using educational, scientific and cultural projects as the main instrument of its activities [6, p. 212-213]. Today, representative offices of the Spanish (Cervantes Institute), Chinese (Confucius Institute), Azerbaijan, Israel, Polish, Czech cultural centers and others have opened in Ukraine. The most active international cultural institutions are the representative offices of the most well-known and expanded foreign cultural centers, in particular the Great Britain (British Council), France (French Institute), Germany (Goethe Institute). Throughout decades, all these organizations have been carrying on consistent work that have been promoting the expansion of contacts between Ukrainian and foreign institutions, enriching experience in various areas of cultural activity. Undoubtedly, their activities have contributed to the general revitalization of social and cultural life in Ukraine and have become a solid foundation for further dialogue, cooperation and understanding.

It is worthwhile to use the experience of the recognized leaders among foreign cultural institutions, which can be helpful for the work of the Ukrainian Institute and the creation of Ukrainian cultural centers abroad. Among the foreign cultural centers that operate in Ukraine, the British Council, the Goethe Institute, and the French Institute are of greatest interest as the most developed and experienced institutions. Each of these organizations has its own structural features, as well as its financing model, directions and activities. Some of them are subject to diplomatic institutions of the country, such as the French Institute, which is a part of the Cooperation and Cultural Action Department of the French Embassy in Ukraine, some of them are independent organizations. Despite of all diversity of the structure, economic situation, forms of work, activities of these institutions are considered to be an important sector of the state policy, and their development requires the comprehensive state support measures.

Typically, the goals of these centers are determined by the political goals and foreign cultural policy of the states they represent. These goals are achieved through the implementation of a number of humanitarian, cultural and scientific and technical programs.

The content of the programs is provided by various state and non-governmental agencies and organizations. Each of these centers carries out various activities. Almost all centers organize language training for those who want to learn the language. In particular, some foreign cultural centers, such as the Goethe-Institut, are mainly oriented towards language spread. It should be noted that the British Council and the French Institute have the most wide network of language courses, including specialized courses, the organization of exams for language certificates (distance or in class), as well as conducting preparatory courses for language exams, etc. Social media tools are widely used to promote language learning (the British Council page on Facebook, mobile applications for learning German from the Goethe Institute, etc.). Within educational projects of the cultural centers they also provide pedagogical assistance to language teachers (seminars for advanced training, providing teaching materials and resources for teachers); as well as providing information and orientation regarding higher education itineraries etc.

Studying the activities of foreign cultural centers in Ukraine shows that, along with the traditional forms of educational activity, considerable attention is paid to projects on information exchange, in particular the development of the library business, media services, information services, documentary services, conducting educational exhibitions. This tendency can be explained by the development of global informatization in the processes of international cooperation. 
In addition, foreign cultural centers show their potential in cultural cooperation. It is represented by an array of cultural and artistic events: film shows (the British Council and the French Institute are partners of the Odessa International Film Festival, they also hold their own film festivals - "New British Cinema"), cultural initiatives (the French Spring Cultural Season, which runs throughout the country during April, starting from 2004, and offers a rich program of cultural events in the main artistic directions, the program of development of the Ukrainian cultural sector Culture Bridges from the British Council, which aims at establishing effective relationships between artists, cultural operators and institutions in Ukraine and the EU), etc.

The organization of various thematic events is one of the main directions of the foreign cultural centers work. Such events include lectures, seminars, youth curricula, exhibitions, concerts, and other cultural events that contribute to a better understanding of the country that presents itself. It should be noted the dynamics of China's cultural activity. The Confucius Institute is currently actively promoting the Chinese culture. In particular, they hold events to spread Chinese cultural traditions, such as exhibitions and workshops on calligraphy, art clipping, Chinese knitting, traditional games, and cooking of Chinese cuisine. In addition, traditional Chinese holidays are celebrated annually: the Feast of the Spring, the Festival of Lanterns, the Dragon Boat Festival, the Day of the Founding of the People's Republic of China [7].

Among cultural projects, projects related to the promotion of reading and book publishing take the leading position. The British Council, the Goethe Institute are interested in translation projects and actively collaborate with translators to increase the volume of literature available to Ukrainian audiences. An annual competition for Ukrainian publishing houses - "Translation of Modern Polish Literature and Essays in Ukrainian", founded in 2006 by the Polish Institute in association with the International Renaissance Foundation, can serve as an example of promoting publishing.

A significant number of such measures convincingly proves the positive effect of such activities. First, it is an additional source of organizational, advocacy, financial and other opportunities that raise the effectiveness of public policy in general, and secondly, cooperation with numerous Ukrainian organizations contributes to strengthening the information and cultural presence of the state abroad, the development of interstate cooperation and fruitful dialogue. Despite the different directions and forms of its activities, foreign cultural centers in their work seek to form an objective and positive image of their country.

Ukraine can take into account the effective models of the experience of foreign cultural centers in developing its own strategy for strengthening its cultural presence in Europe and in the world, in particular, it is advisable to take advantage of their experience in forming the high-quality content for the activities of the Ukrainian Institute. Among the priorities can be the establishment of communication links, participation in international projects and the implementation of joint cultural and artistic programs, cultural and information activities, which will be aimed at disseminating information about the development and achievements of Ukrainian science, education and culture, in particular, such areas as book publishing and translations, promoting the development of cultural industries, etc. Such activities of Ukrainian cultural centers will become an important national instrument of humanitarian policy, presenting different aspects of Ukraine, will promote integration of the country into world cultural processes.

Conclusions. Consequently, the study of European foreign cultural centers experience shows that the activities of such institutions are considered as the most important direction of foreign and cultural policy. Such institutions receive comprehensive state support, and the emergence of new cultural centers in different countries indicates a positive effect of their activities. Over the past decades, the work of foreign cultural centers in Ukraine has been characterized by stable activity and an increase of various forms of cultural cooperation. Despite some differences in the functioning of foreign cultural centers, in general, we can distinguish some important components in their work: educational, cultural, informational ones. The analysis shows that foreign cultural centers usually have a distinct program of actions and a wide range of programs and activities. Ukraine can use the experience of the existing foreign cultural centers functioning, in particular, the main activities.

Prospects for futher research. Further studies should consider the issue of preparing and training stuff for working at international cultural centers.

\section{References:}

1. Ukrayinskyj instytut: m'yaka syla dlya prosuvannya suchasnoyi Ukrayinyu sviti [Ukrainian Institute: soft power for promoting modern Ukraine in the world]. Ministry of Foreign Affairs of Ukraine. Retrieved 06.08.2018 from: http://mfa.gov.ua/ua/press-center/news/54574-ukrajinsykij-institut-mjaka-sila-dlya-prosuvannya-suchasnoji-ukrajini-u-sviti

2. Dosvid funkcionuvannya yevropejskyx instytutiv kulturnoyi dyplomatiyi: vysnovky dlya Ukrayiny. Analitychna zapyska [The experience of European institutions of cultural diplomacy functioning: conclusions for Ukraine. Analytical note]. National Institute for Strategic Studies. Retrieved 05.10.2018 from: http://www.niss.gov.ua/articles/1649/

3. Optymizaciya posylennya kulturnoyi prysutnosti Ukrayiny v Yevropi. Analitychna zapyska [Optimization of the enhancement of Ukraine's cultural presence in Europe. Analytical note]. National Institute for Strategic Studies. Retrieved 05.10.2018 from: http://www.niss.gov.ua/articles/1522/

4. Grachevska T.O. Diyalnist kulturno-informacijnyx centriv yak komponenta kulturnoyi dyplomatiyi [Activities of cultural and information centers as a component of cultural diplomacy].

5. Bogolyubova N., Nykolaeva Yu. Rol zarubezhnix kulturnix centrov v razvytyy sovremennogo mezhkulturnogo sotrudnychestva [The role of foreign cultural centers in the development of modern intercultural cooperation]. Retrieved 10.11.2018 from: www.gramota.net/materials/3/2012/6-2/9.html

6. Bogolyubova N., Nykolaeva Yu. (2009). Mezhkulturnaya kommunykacyya y mezhdunarodnij kulturnij obmen [Intercultural communication and international cultural exchange]. St.-Petersburg : SPBKO, 415 p.

7. Shy Yaczzyun. Instytut Konfuciya - rushnyk, na yakomu rozgortayetsya kulturna spivpracya mizh Ukrayinoyu ta Kytayem [The Confucius Institute is a bridge for cultural cooperation between Ukraine and China]. Ukrainian Association of Sinologists. Retrieved 15.11.2018 from: http://sinologist.com.ua/institut-konfutsiya-rushnik-na-yakomu-r/ 